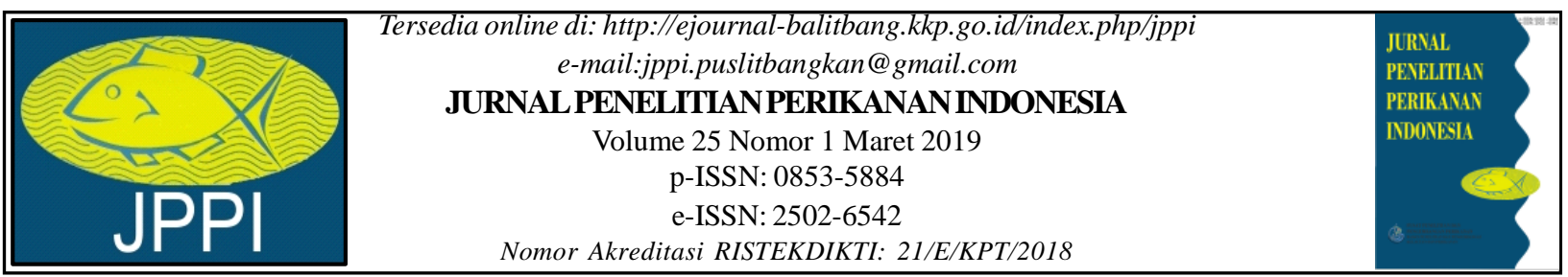

\title{
UJICOBA MINI LINE HAULER PADA KAPAL PANCING ULUR TUNA YANG DIOPERASIKAN DI SEKITAR RUMPON DI SAMUDERA HINDIA
}

\section{TRIAL OF MINI LINE HAULER ON TUNA HAND LINE BOAT OPERATED AROUND FADS IN THE INDIAN OCEAN}

\author{
Agustinus Anung Widodo*1, Wudianto' dan Agus Setiyawan' \\ ${ }^{1}$ Peneliti pada Pusat Riset Perikanan, Jln. Pasir Putih II, Ancol Timur, Jakarta Utara-14430, Indonesia \\ Teregistrasi I tanggal: 27 April 2018; Diterima setelah perbaikan tanggal: 01 Juli 2019; \\ Disetujui terbit tanggal: 12 Juli 2019
}

\begin{abstract}
ABSTRAK
Pancing ulur tuna $\left({ }_{d} \mathrm{HL}\right)$ umumnya dioperasikan di sekitar rumpon dengan tali pancing ${ }_{d} \mathrm{HL}$ ditarik secara manual saat menangkap ikan tuna. Praktik tersebut berpotensi mengakibatkan kecelakaan kerja bagi nelayan dan memakan waktu lama. Salah satu usaha mengurangi potensi kecelakaan kerja nelayan ${ }_{d} \mathrm{HL}$ dan meningkatkan kecepatan tarik tali ${ }_{d} \mathrm{HL}$ saat mendapat tuna, maka telah dilakukan ujicoba mini line hauler pada armada ${ }_{d} \mathrm{HL}$. Ujicoba dilakukan pada armada ${ }_{\mathrm{d}} \mathrm{HL}$ yang berbasis di PPN Prigi pada tahun 2016. Ujicoba dilakukan selama 5 trip penangkapan ${ }_{\mathrm{d}} \mathrm{HL}$ dengan jumlah ulangan percobaan 112 kali penarikan tali $\mathrm{dHL}$ secara manual dan 114 kali penarikan tali ${ }_{\mathrm{d}} \mathrm{HL}$ dengan mini line hauler. Hasil ujicoba menunjukkan bahwa penarikan tali ${ }_{\mathrm{d}} \mathrm{HL}$ secara manual telah mengakibatkan isu kecelakaan kerja berupa luka kulit tangan $A B K$ sebanyak 4 kasus dan cidera pinggang ABK sebanyak 2 kasus. Adapun penggunaan mini line hauler mampu mengurangi isu kesehatan dan keselamatan kerja ABK. Selain itu, penggunaan mini line hauler juga meningkatkan kecepatan penarikan tali ${ }_{d} \mathrm{HL}$ sebesar 1,5 kali dibanding penarikan tali ${ }_{d} \mathrm{HL}$ secara manual. Hasil uji coba juga menunjukkan penggunaan mini line hauler tidak memberikan perbedaan terhadap hasil tangkapan.
\end{abstract}

Kata Kunci: Mini line hauler; pancing ulur tuna; rumpon; Samudera Hindia

\section{ABSTRACT}

Tuna hand line is widely used by fishers for catching yellowfin tuna (Thunnus albacares) and bigeye tuna ( $T$. obesus) around fish aggregating devices (FADs). Manual hauling of ${ }_{d} H L$ potentially leads to work safety issue dan time consuming. Mini line hauler has been introduced to ${ }_{d} \mathrm{HL}$ boat in 2016 to reduce work accident and increasing hauling speed. The trial conducted in ${ }_{d} \mathrm{HL}$ boat based at Prigi Fishing Port, East Java for of $5{ }_{d} H L$ fishing trips. Replication was conducted for manual and mini line hauler by 112 and 144 replicates respectively. The result showed that work accidents occurred to fishers that conducted manual hauling, such as a hand injury (4 fishers) and a low back pain (2 fishers). While, accident was absence in the presence of mini line hauler. It also increased hauling time about 1.5 times than manual hauling. Moreover, catch rate of tuna was not influced by presencing of mini line hauler.

Keywords: Mini line hauler; tuna hand line; FADs; Indian Ocean

\section{PENDAHULUAN}

Perikanan pancing ulur tuna di Indonesia dapat digolongkan sebagai perikanan skala kecil karena umumnya menggunakan kapal berukuran < 10 GT (Yuniarta et al., 2017). Vera et al. (2007) dalam Lepardo et al. (2017) mendefinisikan perikanan tuna skala kecil adalah perikanan tuna yang menggunakan kapal berukuran < 20 GT. Pancing ulur dengan target ikan tuna di sekitar rumpon telah banyak digunakan nelayan di perairan Samudera Hindia (WPP NRI 572 dan 573). Pancing ulur tuna termasuk dalam kelompok 'hook and line' (Seafish, 2005). Terdapat dua jenis pancing ulur tuna yang selama ini dioperasikan 
nelayan yaitu pancing ulur tuna permukaan atau surface tuna hand line $\left({ }_{s} \mathrm{HL}\right)$ dan pancing ulur tuna dalam atau deep tuna hand line $\left({ }_{d} \mathrm{HL}\right)$. Armada pancing ulur tuna biasanya membawa ${ }_{s} \mathrm{HL}$ dan ${ }_{d} \mathrm{HL}$ pada setiap trip operasi penangkapan. Selain ${ }_{s} \mathrm{HL}$ dan ${ }_{d} \mathrm{HL}$ alat tangkap lain yang juga dibawa yaitu pancing tonda (trolling line) dan pancing layang-layang (kites line). Di dalam satu trip operasi penangkapan, keempat jenis alat penangkapan ikan tersebut biasanya dioperasikan bergantian tergantung situasi sumberdaya ikan (tuna) yang berada di sekitar rumpon. ${ }_{s} \mathrm{HL}$ biasanya menangkap tuna berukuran < $5 \mathrm{~kg}$ dan ${ }_{\mathrm{d}}^{\mathrm{HL}} \mathrm{Hmumnya}$ menangkap tuna berukuran $\geq 5 \mathrm{~kg}$.

Basis perikanan ${ }_{s} \mathrm{HL}$ dan ${ }_{d} \mathrm{HL}$ di WPP NRI 572 dan 573 diantaranya di pantai Selatan Nusa Tenggara Timur, Nusa Tenggara Barat, Bali, Jawa dan Barat Sumatera. Adapun basis ${ }_{s} \mathrm{HL}$ dan ${ }_{d} \mathrm{HL}$ di Selatan Jawa di antaranya adalah Sendang Biru-Pondok DadapMalang (Nuramin, 2005), Puger-Jember (Ross, 2008), Prigi-Trenggalek (Ross, et al. 2012). Hargiyatno et al. (2013) menyatakan bahwa di Cilacap dan Pelabuhanratu perikanan pancing ulur tuna mulai berkembang sejak sekitar tahun 2005. Armada ${ }_{s} \mathrm{HL}$ dan ${ }_{d} \mathrm{HL}$ umumnya tidak dilengkapi pesawat bantu untuk menarik tali pancing dan sering mengakibatkan nelayan menghadapi berbagai masalah ketika ${ }_{d} \mathrm{HL}$ dimakan tuna berukuran relatif besar (> $10 \mathrm{~kg}$ ). Masalah yang dihadapi nelayan terutama karena beban kerja berlebih (work overload) yang potensial mengakibatkan kecelakaan kerja dan turunnya mutu ikan hasil tangkapan. FAO (1995) menekankan bahwa kegiatan penangkapan ikan harus memperhatikan kesehatan dan keselamatan nelayan. Turunnya mutu ikan diakibatkan proses penarikan tuna dari saat makan hingga sampai di atas dek sering mamakan waktu hingga 2 jam (WWF, 2011).

Dalam rangka mengurangi timbulnya masalah kesehatan dan keselamatan kerja nelayan serta meningkatkan kecepatan penarikan tali pancing khusunya ${ }_{d} \mathrm{HL}$ tersebut, maka pada tahun 2016 telah dilakukan penelitian melalui ujicoba penggunaan mini line hauler. Ujicoba bertujuan untuk mengetahui perbedaan frekuensi kejadian terkait masalah kesehatan dan keselamatan kerja serta lama waktu yang digunakan untuk menarik tali ${ }_{d} \mathrm{HL}$ yang menggunakan mini line hauler dan yang tidak menggunakan mini line hauler.

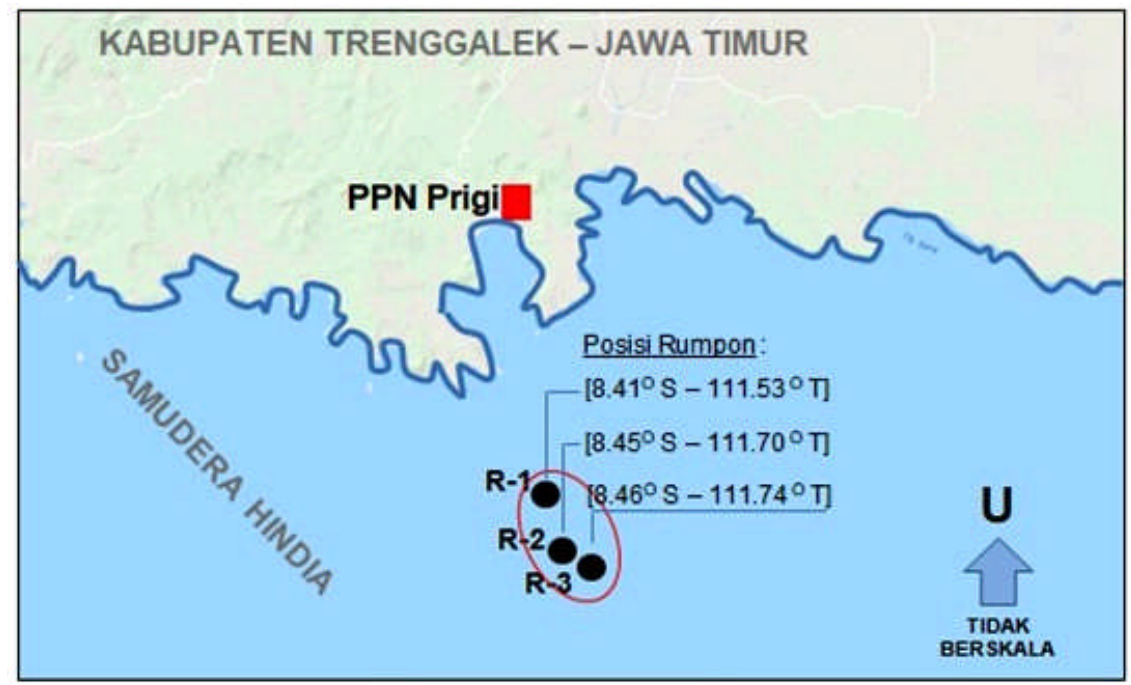

Gambar 1. Lokasi ujicoba penangkapan denga dHL menggunakan mini line hauler di KM. Berdikari.

Figure 1. Location of dHL fishing trial using mini line hauler on board of M.V. Berikari 2.

\section{BAHAN DAN METODE}

Penelitian dilakukan melalui ujicoba penggunaan mini line hauler yang dipasang pada KM. Berdikari 02 (16 GT) yang berbasis di PPN Prigi-Jawa Timur bulan Februari, April, Juni, September dan November tahun 2016. Posisi penangkapan KM. Berdikari 02 selama uji coba adalah di rumpon 1 atau $\mathrm{R}-1$ (koordinat : $8,41^{\circ} \mathrm{S}-111,53^{\circ} \mathrm{T}$ ), rumpon 2 atau R-2 (koordinat : $8,45^{\circ} \mathrm{S}-111,70^{\circ} \mathrm{T}$ ) dan rumpon 2 atau $\mathrm{R}-3$ (koordinat : $8,46^{\circ} \mathrm{S}-111,74^{\circ} \mathrm{T}$ ) seperti disajikan pada Gambar 1.

KM. Berdikari 02 mempunyai anak buah kapal (ABK) yang juga sebagai pemancing sebanyak 5 orang. Pancing ${ }_{d} \mathrm{HL}$ dioperasikan disekitar rumpon dilakukan pada siang dengan target tuna khususnya madidihang (Thunnus albacares) dan tuna matabesar ( $T$. obesus). Rancang bangun dan konstruksi pancing ${ }_{d} \mathrm{HL}$ yang digunakan pada ujicoba ini adalah seperti disajikan pada Gambar 2. 


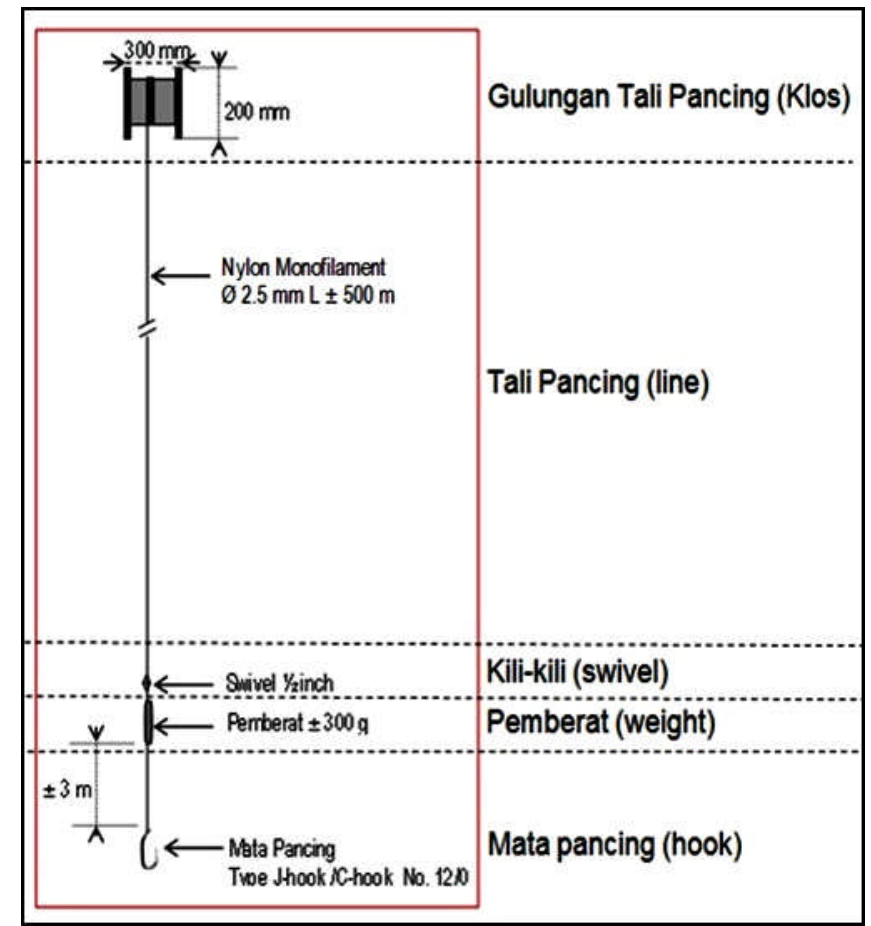

Gambar 2. Rancang bangun dan konstruksi pancing ${ }_{\mathrm{d}} \mathrm{HL}$ pada ujicoba mini line hauler di KM. Berdikari 02. Figure 2. Design and construction of ${ }_{d} H L$ on the trial of mini line hauler in MV. Berdikari 02.

Mini line hauler yang diuji-coba adalah hasil dari penelitian tahun 2015 yang mempunyai spesifikasi teknis sebagaimana disajikan pada Gambar 3 dan Tabel 1.

Disain dan konstruksi mini lain hauler yang diujicoba pada ${ }_{\mathrm{d}} \mathrm{HL}$ adalah mini line hauler dengan sistem penggerak hidraulik. Konstruksi utama mini line hauler terdiri dari unit penggulung tali (line spool) dari bahan kuningan (bronze), motor hidraulik (motor drive), pipa-pipa hidraulik ( hydraulic pipe) dari bahan tembaga (cooper) , pompa hidraulik (hydraulic pump) yang ditempatkan di dalam tangki hidraulik (hydraulic tank) berbahan baja bergalvanis (galvanized stee).

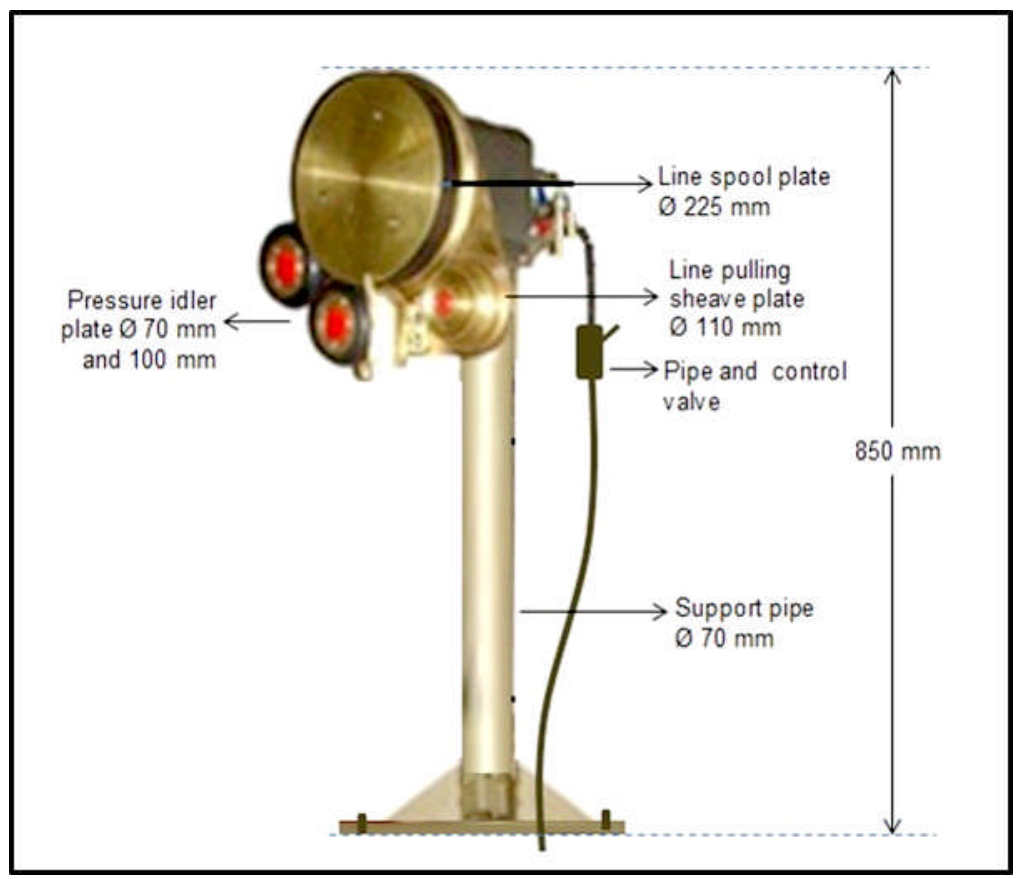

Gambar 3. Disain dan konstruksi mini line hauleryang diujicoba tahun 2016 (Widodo et al., 2016).

Figure 3. Design and construction of mini line hauler which has tested in 2016 (Widodo et al 2016). 
Tabel 1. Spesifikasi mini line hauler yang diujicoba tahun 2016.

Table 1. Specification of mini line hauler that was tested in 2016.

\section{Bagian konstruksi (part of construction) mini line hauler.}

Spesifikasi (specification)

1. Penggulung tali (line spool plate, pressure idler, line pooling sheave)

- Bahan (material)

- $\varnothing$ piringan (diameter of line spool plate)

- Putaran maks (max. RPM)

- $\varnothing$ tali pancing (hook line diameter)

2. Motor hidralik (hydraulic motor)

3. Pompa hidralik (hydraulic pump)

4. Penggerak pompa hidraulik (generataor of hyd. pump)

5. Maksimum kekuatan tarik (maximum fishing traction)

6. Kecepatan operasi tarik (service traction speed)

7. Input (input)

8. Berat (weigh) unit mini line hauler

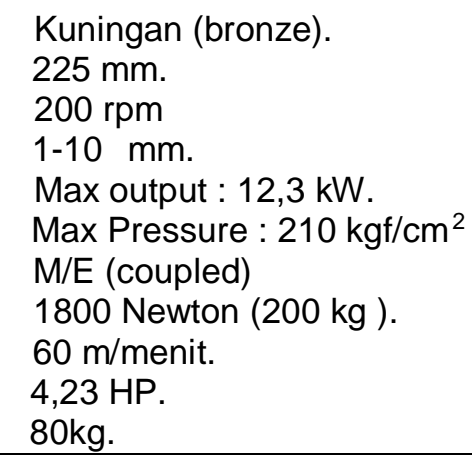

Gambar 4 menunjukkan tata letak dek dan posisi pemasangan mini line hauler di KM. Berikari 02. Gambar 5 menunjukkan rancang bangun, konstruksi

dan sistem hidraulik serta skema kerja mini line hauler di KM. Berdikari 02

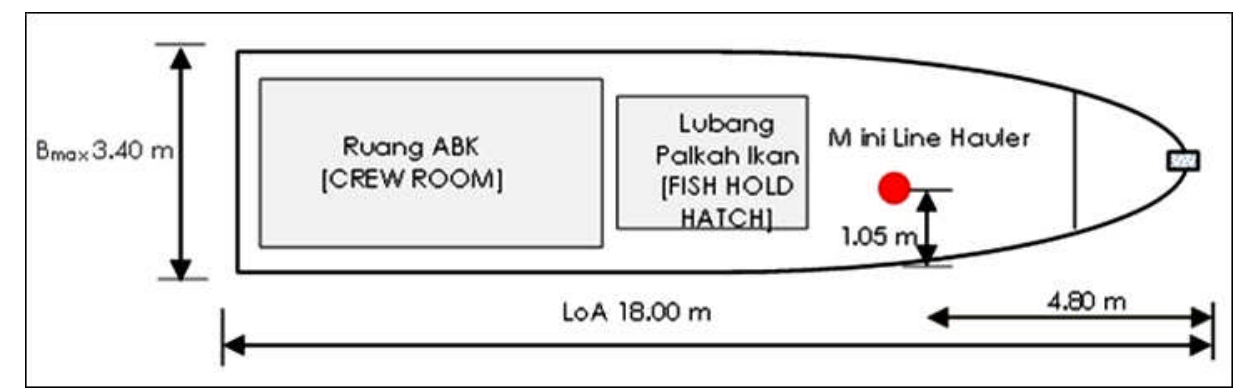

Gambar 4. Tata letak dek dan posisi pemasangan mini line hauler di KM. Berdikar 02.

Figure 4. Deck layout and assembly position of mini line hauler in MV. Berdikari 02.

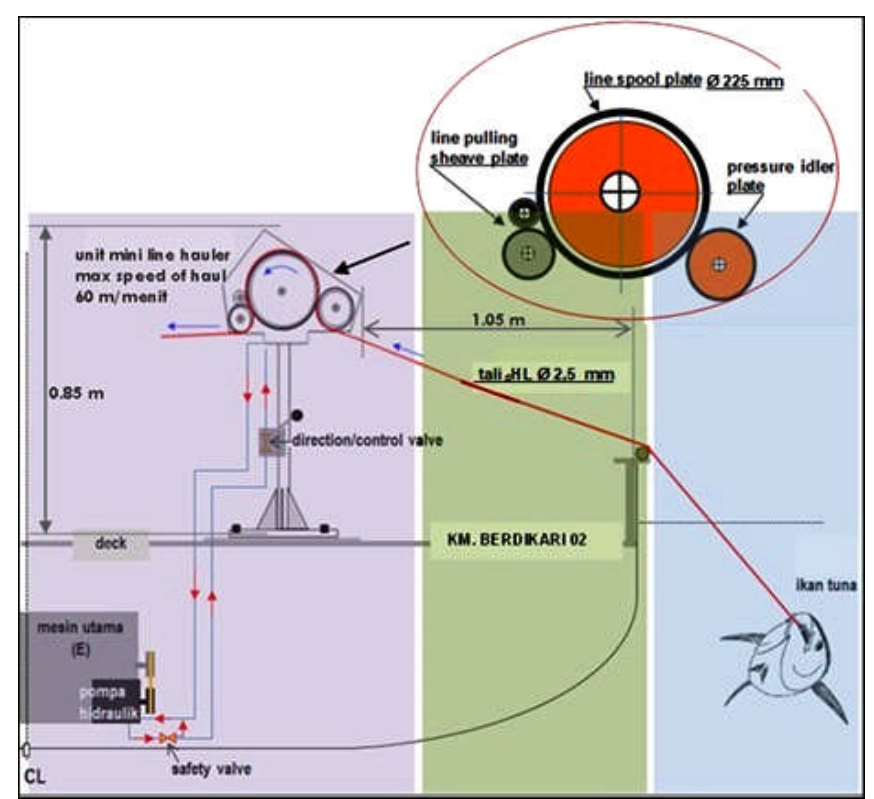

Gambar 5. Rancang bangun, konstruksi dan sistem hidraulik serta skema kerja mini line haulerdi KM. Berdikari 02.

Figure 5. Design, construction and hydraulic system and work schematic diagram of mini line hauler in MV. Berdikari 02. 
Jenis data yang dikumpulkan pada kedua cara penarikan tali pancing ${ }_{d} \mathrm{HL}$ yaitu cara manual (ditarik tangan oleh pemancing) dan penarikan tali pancing ulur tuna menggunakan mini line hauler meliputi: jumlah (bobot) hasil tangkapan dan lama waktu yang dibutuhkan untuk menarik tarik tali pancing ${ }_{\mathrm{d}} \mathrm{HL}$ saat dimakan tuna. Selama 5 trip penangkapan KM. Berdikari 02 yaitu bulan Februari, April, Juni, Sepetember dan November tahun 2016, diperoleh data sebanyak 144 ulangan penarikan tali pancing ulur tuna dengan mini line hauler dan 112 ulangan penarikan tali pancing ${ }_{\mathrm{d}} \mathrm{HL}$ secara manual (tanpa mini line hauler). Kesamaan dua rata-rata hasil tangkapan dan rata-rata kecepatan tarik tali ${ }_{\mathrm{d}} \mathrm{HL}$ diuji secara statistik yang mengacu pada Usman et al. (2008) pada taraf nyata $95 \%$ dan diolah menggunakan Excel. Jika hasil analisis menunjukkan $t_{\text {hitung }}>t_{\text {table }}$ dan $p_{- \text {value }}<0,05$ maka tolak $\mathrm{H}_{0}$ disimpulkan bahwa ada perbedaan ratarata dari kedua perlakukan dan sebaliknya. Hasil dari kedua cara tersebut diperbandingkan dan disajikan dalam bentuk tabel dan grafik. Adapun perbedaan frekuensi terkait isu keselamatan dan kesehatan kerja dianalisis secara deskriptif.

\section{HASIL DAN BAHASAN \\ Hasil}

\section{Ujicoba Mini Line Hauler}

Keselamatan Kerja dan Isu Kesehatan Nelayan

Metoda penangkapan ${ }_{\mathrm{d}} \mathrm{HL}$ di sekitar rumpon adalah setelah kapal sampai di rumpon dan diperkirakan ada tuna disekitarnya, kapal akan mendekat dan diikatkan pada rumpon. Para $A B K$ atau nelayan pemancing mulai mengoperasikan pancing ${ }_{\mathrm{d}} \mathrm{HL}$ yang telah disiapkan. Ikan tuna yang telah terkena pancing ${ }_{d} \mathrm{HL}$ ditarik ke atas dek kapal secara manual (tanpa menggunakan mini line hauler) dan dengan mini line hauler. Hasil pengamatan yang dilakukan oleh observer menunjukkan bahwa selama 5 trip penangkapan dengan 112 kali penarikan tali $\mathrm{dHL}$ tanpa mini line hauler terjadi kecelakaan kerja ABK (pemancing) sebanyak 4 kasus dan kesehatan kerja 2 kasus. Kecelakaan kerja berupa luka kulit tangan karena tergesek tali pancing ${ }_{\mathrm{d}} \mathrm{HL}$ dan isu kesehatan yang diderita ABK berupa sakit pinggang (lowback pain). Pengamatan terhadap 114 kali ulangan penarikan tali pancing $\mathrm{dHL}$ dengan mini line hauler menunjukkan bahwa tidak terjadi isu kecelakaan dan kesehatan kerja ABK.

\section{Kecepatan Tarik Tali ${ }_{d} \mathrm{HL}$}

Selama 5 trip penangkapan tuna di KM. Berdikari 02 berhasil diamati 112 kali ulangan penarikan tali ${ }_{d} \mathrm{HL}$ secara manual dan 144 kali menggunakan mini line hauler. Hasil pengamatan terhadap ${ }_{d} \mathrm{HL}$ yang ditarik secara manual menunjukkan bahhwa berat tuna hasil tangkapan 2,7-63,1 kg / ekor dan kecepatan tarik tali ${ }_{d} \mathrm{HL}$ antara 1,4-44,3 meter/menit. Hasil pengamatan terhadap penarikan tali ${ }_{\mathrm{d}} \mathrm{HL}$ yang menggunakan mini line hauler menunjukkan bahwa berat tuna hasil tangkapan antara 2,5-66,2 kg dan kecepatan tarik tali ${ }_{d} \mathrm{HL}$ saat dimakan tuna antara 6,9 $-45,5$ meter/menit. Perbedaan kecepatan tarik tali ${ }_{\mathrm{d}} \mathrm{HL}$ secara manual dan menggunakan mini line hauler adalah 1,3-5,5 meter/menit. Perbedaan kecepatan tarik tali meningkat sesuai ukuran ikan tuna yang tertangkap (Tabel 2) dan hal tersebut membuktikan bahwa penggunaan mini line hauler telah meningkatkan kecepatan tarik tali ${ }_{\mathrm{d}} \mathrm{HL}$ (Gambar 6).

Tabel 2. Kecepatan tarik tali ${ }_{\mathrm{d}} \mathrm{HL}$ yang menggunakan dan yang tidak menggunakan mini line hauler hasil ujicoba tahun 2016.

Table 2. Pulling speed of ${ }_{d} H L$ line using and not using mini line hauler based on trials in 2016.

\begin{tabular}{|c|c|c|c|}
\hline \multirow{2}{*}{$\begin{array}{c}\text { Selang Ukuran Berat Ikan } \\
\text { (Interval of Fish Weight) } \\
\text { (kg) }\end{array}$} & \multicolumn{2}{|c|}{ Kecepatan Tarik Tali ${ }_{d} \mathrm{HL}-$ Pulling Speed of ${ }_{d} H L$ Line ( $\left.\mathrm{m} / \mathrm{minute}\right)$ ) } & \multirow{2}{*}{$\begin{array}{c}\text { Perbedaan Kecepatan tarik } \\
\text { (Diverence of Pulling Time) } \\
\text { (m/minute) }\end{array}$} \\
\hline & $\begin{array}{c}\text { Menggunakan Mini Line Hauler } \\
\text { (Using Mini Line Hauler) }\end{array}$ & $\begin{array}{l}\text { Tanpa Mini Line hauler } \\
\text { (Non-Mini Line Hauler) }\end{array}$ & \\
\hline$<5$ & 45,5 & 44,3 & 1,3 \\
\hline $5-10$ & 22,5 & 20,9 & 1,6 \\
\hline $11-15$ & 17,3 & 14,3 & 3,0 \\
\hline $16-20$ & 10,9 & 7,1 & 3,8 \\
\hline $21-25$ & 9,4 & 5,2 & 4,2 \\
\hline $26-30$ & 8,0 & 3,6 & 4,4 \\
\hline $31-35$ & 7,6 & 2,9 & 4,7 \\
\hline $36-40$ & 7,3 & 2,2 & 5,1 \\
\hline $41-45$ & 7,1 & 2,0 & 5,1 \\
\hline $46-50$ & 7,0 & 1,9 & 5,1 \\
\hline $51-55$ & 6,9 & 1,8 & 5,1 \\
\hline $56-60$ & 6,9 & 1,7 & 5,2 \\
\hline $61-65$ & 6,9 & 1,5 & 5,4 \\
\hline $66-70$ & 6,9 & 1,4 & 5,5 \\
\hline
\end{tabular}




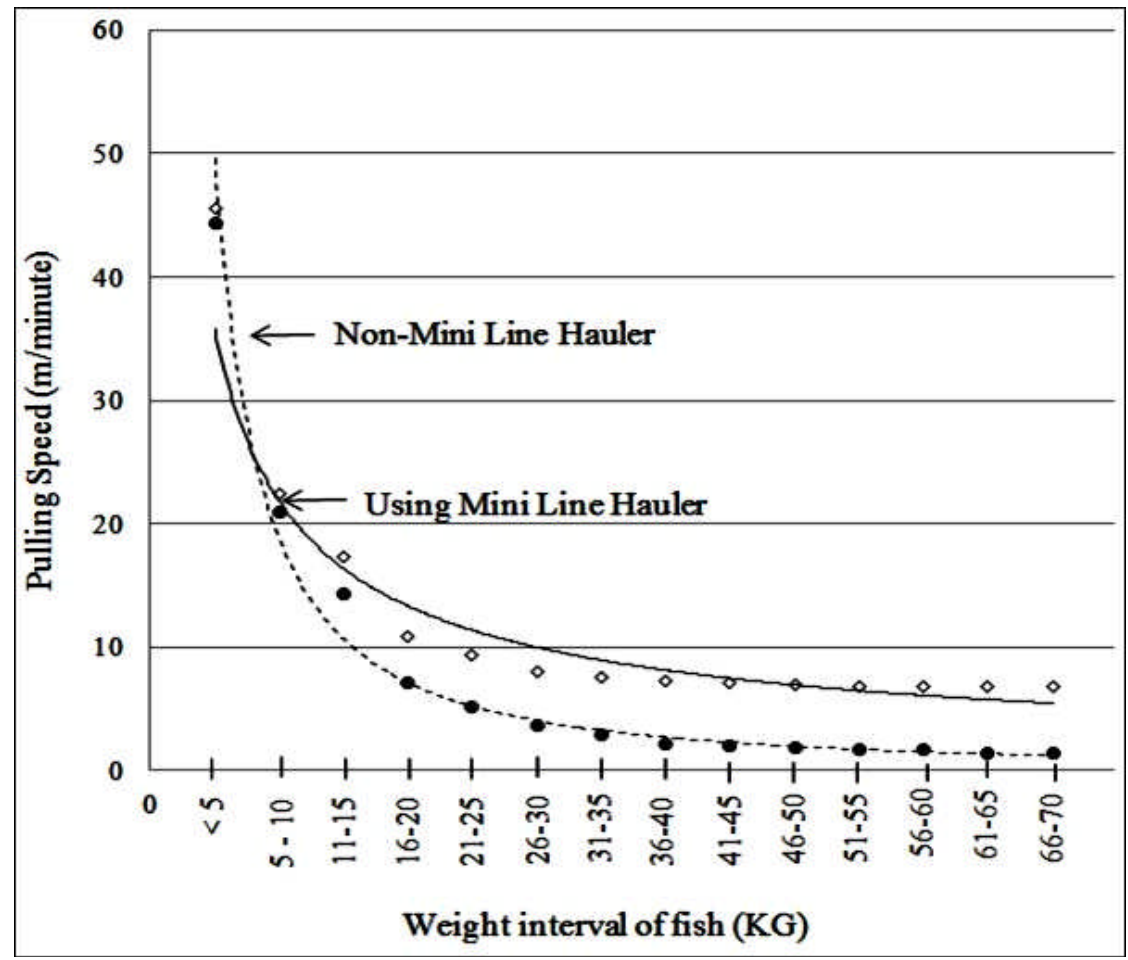

Gambar 6. Grafik kecepatan tali pancing ${ }_{\mathrm{d}} \mathrm{HL}$ yang ditarik menggunakan mini line hauler dan ditarik secara manual dengan beban tarik madidihang (Thunnus albacares) selama uji coba tahun 2016.

Figure 6. Graphic of speed of haul the line of ${ }_{d} H L$ pulled by using mini line hauler and manually by hands with the pull load of yellowfin tuna (Thunnus albacares) catch-during the trials in 2016.

\section{Hasil Tangkapan}

Hasil kegiatan 5 trip ujicoba ( 1 trip penangkapan antara 7-10 hari) menunjukan bahwa jenis ikan yang tertangkap pancing ulur tuna di sekitar rumpon tercatat sebanyak 12 species. Total tangkapan selama 5 trip penangkapan adalah $5419 \mathrm{~kg}$ dengan rata-rata 1083,8 kg per trip (Tabel 3) dan jenis ikan hasil tangkapan didominasi tuna madididang
(Thunnus albacares) sekitar $77,4 \%$. Adapun hasil tangkapan sampingan (bycatch) diantaranya adalah stuhuk hitan (Makaira indica), setuhuk loreng (Tetrapturus audax), ikan layaran (Istiophorus spp.) ikan tumbuk (Tetrapturus angustirostris), hiu mako (Isurus paucus), hiu selendang (Prionace glauca) dan hiu koboi (Carcharhinus longimanus) sebagaimana disajikan pada Tabel 4.

Tabel 3. Rata-rata hasil tangkapan ${ }_{\mathrm{d}} \mathrm{HL}$ (kg per trip) selama observasi tahun 2016.

Table 3. Average number of catch ${ }_{d} H L$ (kg per trip) during observation in 2016.

\begin{tabular}{cccc}
\hline \multirow{2}{*}{$\begin{array}{c}\text { Trip penangkapan } \\
\text { (Fishing trip) }\end{array}$} & \multicolumn{3}{c}{ Hasil tangkapan $\mathrm{d}_{\mathrm{dL}} 5$ trip (Catch of ${ }_{d} H L$ of 5 trips) $(\mathrm{kg})$} \\
\cline { 2 - 4 } & $\begin{array}{c}\text { Dengan mini line hauler } \\
\text { (With mini line hauler) }\end{array}$ & $\begin{array}{c}\text { Tampa mini line hauler } \\
\text { (Without mini line hauler) }\end{array}$ & Total (total) \\
\hline 1 & 573 & 572 & 1145 \\
2 & 501 & 505 & 1006 \\
3 & 613 & 578 & 1191 \\
4 & 515 & 510 & 1025 \\
5 & 524 & 528 & 1052 \\
\hline Rata-rata (average) & 545,2 & 538,6 & 1083,8 \\
\hline
\end{tabular}


Tabel 4. Jenis dan jumlah hasil tangkapan ${ }_{\mathrm{d}} \mathrm{HL}$ per trip selama observasi tahun 2016.

Table 4. Species and number of catch dHL per trip during observation in 2016.

\begin{tabular}{|c|c|c|c|c|c|c|c|c|c|c|c|c|c|}
\hline \multirow{3}{*}{ Jenis ikan (Species) } & \multicolumn{13}{|c|}{ Hasil tangkapan per Trip penangkapan - Catch per fishing trip (kg) } \\
\hline & \multicolumn{2}{|c|}{ Trip ke-1 } & \multicolumn{2}{|c|}{ Tríp ke-2 } & \multicolumn{2}{|c|}{ Trip ke-3 } & \multicolumn{2}{|c|}{ Trip ke-4 } & \multicolumn{2}{|c|}{ Trip ke-5 } & \multicolumn{2}{|c|}{ Total } & \multirow[t]{2}{*}{$\%$} \\
\hline & A & B & A & B & A & B & A & B & A & B & A & B & \\
\hline $\begin{array}{l}\text { Madidihang } \\
\text { (Thunnus albacares) }\end{array}$ & 440 & 446 & 360 & 352 & 483 & 492 & 397 & 372 & 435 & 415 & 2115 & 2077 & 77,4 \\
\hline $\begin{array}{l}\text { Tuna matabesar } \\
\text { (T.obesus) }\end{array}$ & 18 & 15 & 0 & 28 & 21 & 0 & 34 & 0 & 33 & 28 & 106 & 71 & 3,3 \\
\hline $\begin{array}{l}\text { Setuhuk hitam } \\
\text { (Makaira indica) }\end{array}$ & 22 & 24 & 30 & 22 & 39 & 0 & 22 & 0 & 0 & 43 & 113 & 89 & 3,7 \\
\hline $\begin{array}{l}\text { Setuhuk breng } \\
\text { (Tetropturus audax) }\end{array}$ & 0 & 0 & 0 & 47 & 0 & 0 & 0 & 41 & 0 & 30 & 0 & 118 & 2,2 \\
\hline $\begin{array}{l}\text { Ikan pedang } \\
\text { (Xïphias gladius) }\end{array}$ & 0 & 0 & 0 & 0 & 0 & 0 & 0 & 52 & 0 & 0 & 0 & 52 & 1,0 \\
\hline $\begin{array}{l}\text { Ikan hyaran } \\
\text { (Istiophorus spp.) }\end{array}$ & 18 & 0 & 0 & 0 & 0 & 26 & 0 & 0 & 0 & 0 & 18 & 26 & 0,8 \\
\hline $\begin{array}{l}\text { Hin mako } \\
\text { (Isurus paucus) }\end{array}$ & 0 & 0 & 55 & 0 & 39 & 0 & 42 & 0 & 36 & 0 & 172 & 0 & 3,2 \\
\hline $\begin{array}{l}\text { Hin selendang } \\
\text { (Prionace glauca) }\end{array}$ & 38 & 0 & 0 & 0 & 0 & 0 & 0 & 0 & 0 & 0 & 38 & 0 & 0,7 \\
\hline $\begin{array}{l}\text { Hin koboi } \\
\text { (Carcharhinus longimanus) }\end{array}$ & 0 & 47 & 0 & 0 & 0 & 0 & 0 & 0 & 0 & 0 & 0 & 47 & 0,9 \\
\hline $\begin{array}{l}\text { (Scomberomorus } \\
\text { commerson) }\end{array}$ & 0 & 0 & 0 & 38 & 17 & 0 & 0 & 21 & 0 & 0 & 17 & 59 & 1,4 \\
\hline $\begin{array}{l}\text { Lemadang (Coryphaena } \\
\text { hippurus) }\end{array}$ & 37 & 40 & 56 & 0 & 14 & 44 & 20 & 24 & 20 & 12 & 147 & 120 & 4,9 \\
\hline $\begin{array}{l}\text { Wahoo } \\
\text { (Acanthocybium solandri) }\end{array}$ & 0 & 0 & 0 & 18 & 0 & 16 & 0 & 0 & 0 & 0 & 0 & 34 & 0,6 \\
\hline T o t a $1(\mathrm{~kg})$ & 573 & 572 & 501 & 505 & 613 & 578 & 515 & & 524 & 528 & 2726 & 2693 & 100 \\
\hline Total tangkapan (catch) per tri & 114 & & 100 & & 119 & & 10 & & $10^{-}$ & & & 5419 & \\
\hline $\begin{array}{l}\text { Jumlah hari memancing/trip } \\
\text { (fishing day/trip) }\end{array}$ & 9 & & 8 & & 10 & & 8 & & 7 & & & & \\
\hline
\end{tabular}

\section{Bahasan}

Terjadinya isu kesehatan yang diderita ABK berupa sakit pinggang (lowback pain) terutama disebabkan beban kerja lebih (over loaded) saat ABK menarik ikan tuna berukuran lebih dari $16 \mathrm{~kg}$. Lee at al. (2014) menyatakan bahwa rata-rata kekuatan tarik dengan tangan tanpa pesawat bantu (manual) orang dewasa pada posisi berdiri adalah $\pm 16 \mathrm{~kg}$. Hasil riset Junchi et al. (2015) dan Haiyang et al. (2016), menyatakan tuna madidihang yang mampu menghasilkan kekuatan tarik dinamis $\left(\mathrm{F}_{\mathrm{d}}\right) \pm 16 \mathrm{~kg}$ atau $\pm 157 \mathrm{~N}$ adalah madidihang yang berukuran berat $\pm 17 \mathrm{~kg}$ dengan kecepatan renang $20 \mathrm{~m} /$ detik. Jika pancing ${ }_{\mathrm{d}} \mathrm{HL}$ menangkap tuna madidihang berukuran berat $>17$ $\mathrm{kg}$ maka berpotensi menimbulkan isu kecelakaan dan kesehatan kerja bagi ABK karena mengalami beban lebih kerja (work over loaded) sakit pinggang (low back pain), hernia (hernia nucleus pulposus) atau patah tulang (fracture) sebagaimana termaktub dalam UU No. 1 Tahun 1970 tentang Kesehatan (Sekkretariat Negara Republik Indonesia, 1970). Tidak terjadinya isu kecelakaan dan kesehatan kerja $\mathrm{ABK}$ pada ${ }_{\mathrm{d}} \mathrm{HL}$ yang menggunakan mini line hauler membuktikan bahwa penggunaan mini line hauler telah mengurangi bahkan meniadakan terjadinanya isu kecelakaan dan kesehatan kerja $\mathrm{ABK}{ }_{\mathrm{d}} \mathrm{HL}$.

Penggunaan mini line hauler telah meningkatkan efisiensi yaitu meningkatkan kecepatan tarik tali pancing ${ }_{d} \mathrm{HL}$ saat dimakan tuna. Secara keseluruhan dari sebanyak 112 kali ulangan penarikan tali ${ }_{\mathrm{d}} \mathrm{HL}$ tanpa mini line hauler rata-rata kecepatan tarik talinya adalah $7,91 \mathrm{~m} /$ menit dan penarikan tali ${ }_{d} \mathrm{HL}$ dengan mini line hauler adalah $12,16 \mathrm{~m} /$ menit. Dengan demikian kecepatan penarikan tali ${ }_{\mathrm{d}} \mathrm{HL}$ dengan mini 
line hauler 1,5 kali lebih cepat dibanding tanpa line hauler atau secara manual. Hasil uji-t-paired two sample for mean pada taraf nyata $95 \%$ menunjukkan bahwa nilai $\mathrm{t}_{\text {hitung }}=11,45$ dan $\mathrm{t}_{\text {tabel }}=2,16$ dan $\mathrm{p}$ - $_{\text {value }}$ 1,83E-08 (Lampiran 1) menunjukkan bahwa ada perbedaan nyata terhadap kecepatan tarik tali ${ }_{d} \mathrm{HL}$ dengan dan tanpa mini line hauler. Penggunaan mini line haulerpada ${ }_{d} \mathrm{HL}$ tuna merupakan kemajuan teknis di dalam penerapan teknologi dalam rangka peningkatan efisiensi praktik penangkapan ikan. Valdemarsen (2001) mencatat bahwa pengembangan teknologi pada perikanan tangkap telah meningkatkan efisiensi dalam praktik penankapan ikan. Sementara itu Squires \& Vestergaard (2013) mengatakan juga bahwa kemajuan teknis telah berkontribusi pada pertumbuhan dan perkembangan perikanan.

Hasil uji-t-paired two sample for mean pada taraf nyata $95 \%$ menunjukkan bahwa nilai $\mathrm{t}_{\text {hitung }}=0,904$; $\mathrm{t}_{\text {tabel }}=2,776$ dan $\mathrm{p}-_{\text {value }} 0,416$ (Lampiran 2). Dari hasil tersebut menunjukkan bahwa tidak ada perbedaan nyata terhadap jumlah hasil tangkapan ${ }_{d} \mathrm{HL}$ ketika ditarik dengan atau tanpa mini line hauler saat dimakan ikan (tuna). Hal tersebut berarti bahwa penggunaan mini line hauler pada ${ }_{d} \mathrm{HL}$ tidak mempengaruhi kemampuan tangkap (catchability) ${ }_{d} \mathrm{HL}$. Hasil penelitian oleh Evans et al. (2008) mengatakan bahwa kemampuan tangkap (catchability) pancing rawai terhadap tuna khususnya tuna mata besar tidak dipengaruhi hal teknis seperti halnya cara penarikan tali pancing, namun lebih dipengaruhi oleh faktor lain diantaranya lingkungan, tingkah laku ikan dan daerah operasi penangkapan. Dalam melakukan stadarisasi catch per unit effort atau CPUE hand line, Winker et al. (2013) juga tidak memasukkan faktor kecepatan tarik tali hand line karena tidak tidak berpengaruh terhadap CPUE-nya.

\section{KESIMPULAN}

Penggunaan mini line hauler pada ${ }_{d} \mathrm{HL}$ telah mengeliminir hingga $100 \%$ kejadian kecelakaan kerja berupa luka kulit karena tergesek tali pancing dan isu kesehatan berupa sakit pinggang karena beban kerja berlebih nelayan ${ }_{d} \mathrm{HL}$. Penggunaan mini line hauler juga telah meningkatkan rata-rata kecepatan tarik tali pancing ${ }_{d} \mathrm{HL}$ dari $7,91 \mathrm{~m} /$ menit menjadi 12,16 $\mathrm{m} /$ menit, dengan demikian kecepatan penarikan tali ${ }_{d} \mathrm{HL}$ dengan mini line hauler 1,5 kali lebih cepat dibanding tanpa line hauler.

\section{PERSANTUNAN}

Paper ini merupakan bagian dari hasil kegiatan Pengembangan Teknologi Adpatif Lokasi (PETAL) berjudul : Model Penerapan Rancang Bangun Mini
Line hauleruntuk Penangkapan Tuna dengan Pancing Ulur di Sekitar Rumpon yang dibiayai APBN Pusat Penelitian Dan Pengembangan Perikanan tahun 2016. Penulis mengucapkan terima kasih kepada Nahkoda dan ABK KM. Berdikari 02 yang telah membantu dan mendukung kegiatan ujicoba mini line hauler, SMK Negeri I Watuliomo Prigi yang telah mengikut sertakan 6 siswanya sebagai observer selama ujicoba mini line hauler.

\section{DAFTAR PUSTAKA}

Evans, K., Langley, A., Clear, N.P., Williams, P., Patterson, T., Sibert, J., Hampton, J., \& Gunn, J.S. (2008) Behaviour and habitat preferences of bigeye tuna (Thunnus obesus) and their influence on longline fishery catches in the western Coral Sea. Can. J. Fish. Aquat. Sci. 65, 2427-2443.

FAO (1995). Code of cunduct for responsible fisheries, ISBN 92-5-103834-5. Rome, FAO. 1995. 41 p.

Hargiyatno, I., Wudianto \& Anggawangsa, R. (2013). Perikanan pancing ulur di Palabuhanratu: Kinerja Teknis Alat Tangkap. J.Lit.Perikan.Ind. 19(3), 121130. DOI: http://dx.doi.org/10.15578/ jppi.19.3.2013.121-130.

Haiyang, L., Liming, S., Junting, Y., \& Junchi, M.A. (2016). The mechanical properties of ring hook and circle hook, Journal of Fisheries of China: 10000615(2016)06-0965-11, DOI: 10.11964/ jfc.20150709997, 40(6), 965-975.

Junchi, M.A., Junting, Y., \& Liming, S. (2015). Mechanical properties of tuna long-line hook based on finite element analysis method, Journal of Fisheries of China : 1000-0615 (2015)11-1742-10, DOI:10.11964/jfc.201410009500, 39(11), 17421751.

Lee, J., Nussbaum, M.A., \& Kyung, G. (2014). Effect of work experience on work methods during dynamic pushing and pullung. Elsevier: International Journal of Ergonomics, 44, 647-653.

Lepardo, M.D.D., Sarmiento, J.M.P., Digal, L. N., \& Balgos, C.Q. (2017). Underreporting of Tuna Catch: Implications to Technical Efficiency of Handline Fishing Vessels in General Santos City, Philippines. BANWA B (2017) 12:res004. 17p. ojs.upmin.edu.ph. file:///C:/Users/user1/Downloads/321-321-1-PB.pdf. 
Nuramin M. (2005). Prospek pengembangan perikanan tuna di Sendang Biru, Kabupaten Malang, Jawa Timur. [Skripsi]. Bogor (ID): Institut Pertanian Bogor.

Seafish. (2005). Basic fishing methods. Seafish Flume Tank, Manchester Street Hull.

Sekretaris Negara Republik Indonesia (1970). Undang-Undang No 1 tahun 1970. Tentang keselamatan kerja. Diundangkan di Jakarta pada tanggal 12 Januari 1970. 11 Bab-18 Pasal.

Squires, D., \& Vestergaard, N. (2013). Technical change in fisheries. Marine Policy (Journal), 42, p. 286-292, Elsevier, journal homepage: www.elsevier.com/locate/marpol.

Ross, A. (2008). Peluang ekspor tuna segar dari PPI Puger (Tinjauan Aspek Kualitas dan Aksesbilitas Pasar). [Skripsi]. Bogor (ID): Institut Pertanian Bogor.

Ross, A., Wiyono E.S., \& Nurani T.W. (2012). Persepsi sosial stakeholder perikanan tangkap di PPN Prigi, Trenggalek. Buletin PSP. 20(3), 229237

Usman, H., \& Akbar, R.P.S. (2008). Pengantar statistika (Edisi kedua), Jakarta, ISBN : 979-526222-X, 363 halaman.

Valdemarsen, J.W. (2001). Technological trends in capture fisheries. Ocean and Coastal Management (Journal), 44, p. 635-651. Elsevier, https://doi.org/ 10.1016/S0964-5691(01)00073-4.
Widodo, A.A, A. Setiyawan, A. Adha, T. Mahulette, S. Wibowo, H.H. Latief, K. Susanto, R. Fauziah, O. Ria (2016). Model Penerapan Rancang Bangun Mini Line hauleruntuk Penangkapan Tuna dengan Pancing Ulur di Sekitar Rumpon. Pengembangan Teknologi Adaptif Lokasi, Pusat Penelitian Dan Pengembangan Perikanan Badan Litbang Kelautan dan Perikanan Kementerian Kelautan dan Perikanan 2016 LAPORAN TEKNIS. 42 halaman.

Winker, H., Kerwath, S.E., \& Attwood, C.G. (2013) Comparison of two approaches to standardize catch-per-unit-effort for targeting behaviour in a multispecies hand-line fishery. Fisheries Research (Journal), 139, p.118-131. Elsevier, journal homepage: www.elsevier.com/locate/fishres.

WWF (2011). Perikanan Tuna. Panduan Penangkapan dan Penanganan. Seri Panduan Perikanan Skala Kecil. Versi 1 Oktober 2011. 26p.

Yuniarta, S., van Zwietenb, P.A.M., Groenevelda, R. A., Wisudo, S.H., \& van lerlanda, E.C. (2017). Uncertainty in catch and effort data of small- and medium-scale tuna fisheries in Indonesia: Sources, operational causes and magnitude. Fisheries Research (Journal), 193, p.173-183. Elsevier, journal homepage: www.elsevier.com/locate/ fishres. 
Lampiran 1. Hasil t-Test: Paired Two Sample for Means kecepatan tarik tali ${ }_{\mathrm{d}} \mathrm{HL}$.

Appendix 1. Result of t-Test : Paired Two Sample for Means of hauling speed of ${ }_{d} H L$.

\begin{tabular}{lrr}
\hline & $\begin{array}{c}\text { Dengan mini line } \\
\text { hauler }(\text { With mini } \\
\text { line hauler })\end{array}$ & $\begin{array}{c}\text { Tampa mini line hauler } \\
\text { (Without mini line hauler })\end{array}$ \\
\hline Mean & 12,15714286 & 7,914285714 \\
Variance & 113,7472527 & 142,1920879 \\
Observations & 14 & 14 \\
Pearson Correlation & 0,998674834 & \\
Hypothesized Mean Difference & 0 & \\
df & 13 & \\
t Stat & 11,449163 & \\
P $(\mathrm{T}<=t)$ one-tail & $1,83206 \mathrm{E}-08$ & \\
t Critical one-tail & 1,770933396 & \\
P $(\mathrm{T}<=t)$ two-tail & $3,66411 \mathrm{E}-08$ & \\
t Critical two-tail & 2,160368656 & \\
\hline
\end{tabular}

Lampiran 2. Hasil t-Test : Paired Two Sample for Means hasil tangkapan ${ }_{\mathrm{d}} \mathrm{HL}$.

Appendix 2. Resutl of t-Test : Paired Two Sample for Means of ${ }_{d} H L$ catch.

\begin{tabular}{lrr}
\hline & $\begin{array}{c}\text { Dengan mini line } \\
\text { hauler (With mini } \\
\text { line hauler) }\end{array}$ & $\begin{array}{c}\text { Tanpa mini line hauler } \\
\text { (Without mini line hauler) }\end{array}$ \\
\hline Mean & 545,2 & 538,6 \\
Variance & 2171,2 & 1181,8 \\
Observations & 5 & 5 \\
Pearson Correlation & 0,963479588 & \\
Hypothesized Mean Difference & 0 & \\
df & 4 & \\
t Stat & 0,904364184 & \\
P(T<=t) one-tail & 0,208472766 & \\
t Critical one-tail & 2,131846786 & \\
P $(\mathrm{T}<=t)$ two-tail & 0,416945533 & \\
t Critical two-tail & 2,776445105 & \\
\hline
\end{tabular}

